\title{
Ancylobacter polymorphus sp. nov. and Ancylobacter vacuolatus sp. nov.
}

\author{
Correspondence \\ Wen Xin Chen \\ wenxin_chen@263.net \\ Yu Guang Zhou \\ zhouyg@im.ac.cn
}

\author{
Yu Hua Xin, ${ }^{1,2}$ Yu Guang Zhou ${ }^{2,3}$ and Wen Xin Chen ${ }^{1}$ \\ ${ }^{1}$ China Agricultural University, Beijing 100094, People's Republic of China \\ ${ }^{2,3}$ China General Microbiological Culture Collection Center ${ }^{2}$ and State Key Laboratory of \\ Microbial Resources ${ }^{3}$, Institute of Microbiology, Chinese Academy of Sciences, \\ Beijing 100080, People's Republic of China
}

According to its curved, small rod shape, Ørskov named the genus Microcyclus in 1928 (Ørskov, 1928). However, because of the prior existence of a fungal genus of the same name [Microcyclus Saccardo, Sydow \& P. Sydow 1904; Sydow \& Sydow (1904)], Raj (1983) substituted the name Ancylobacter. Members of Ancylobacter are widespread in nature, particularly in aquatic environments, such as lowland marshes, water reservoirs and wastewater treatment ponds (Raj, 1989). Members of the genus seem to play an important ecological role in oligotrophic methylotrophy (Raj, 1989). Before Ancylobacter rudongensis was described (Xin et al., 2004), there was only one species in the genus, Ancylobacter aquaticus. In addition, various investigators have isolated several closely related bacteria from different countries, for instance 'Renobacter vacuolatum' (Nikitin, 1971) and 'Ancylobacter polymorphus' (Raj, 1989). However, these species names were neither included in the Approved Lists nor later validly published.

In this study, we studied the physiological, genetic and phylogenetic characteristics of ' $R$. vacuolatum' DSM 1277 and ' $A$. polymorphus' DSM 2457. Phylogenetic analysis showed that strains DSM 1277 and DSM 2457 belonged to the genus Ancylobacter. DNA-DNA hybridization indicated that each of these strains represents a distinct novel species.

A. aquaticus DSM $101^{\mathrm{T}}$ and Ancylobacter spp. DSM 1227 and DSM 2457 were obtained from DSMZ. A. rudongensis AS $1.1761^{\mathrm{T}}$ was obtained from China General Microbiological Culture Collection Center. These strains were

The GenBank/EMBL/DDBJ accession numbers for the 16S rRNA gene sequences of strains DSM $1277^{\top}$ and DSM $2457^{\top}$ are AY211515 and AY211516. incubated at $30^{\circ} \mathrm{C}$ in Ancylobacter-Spirosoma medium (DSMZ medium 7; DSMZ, 1998). In order to test the requirement for $\mathrm{O}_{2}$, the strains were incubated in Ancylobacter-Spirosoma medium with $0 \cdot 2 \%$ agar. Growth with carbon sources was tested in the basal medium supplemented with vitamins at $0 \cdot 1 \%$ final concentrations of carbon sources. The production of acid and gas from carbohydrates was determined using the method of Hugh \& Leifson (1953). Nitrogenase activity was tested as described by Hanson \& Phillips (1981). DNase was tested as described by Schreier (1969). Indole production, methyl red and VogesProskauer tests, nitrate reduction and denitrification, $\mathrm{H}_{2} \mathrm{~S}$ production, milk reaction, starch hydrolysis, gelatin liquefaction, aesculin hydrolysis, urease, lipase (Tween 80), arginine dihydrolase and phenylalanine deaminase were tested according to the methods of Smibert \& Krieg (1981).

Genomic DNAs were extracted according to the method of Marmur (1961). The G $+\mathrm{C}$ content of the DNA was tested by the thermal denaturation method (Marmur \& Doty, 1962). Levels of DNA-DNA hybridization were determined from the initial DNA-DNA liquid reassociation rate as described by De Ley et al. (1970). Renaturation rates were determined in $2 \times$ SSC on a model Lambda Bio $20 \mathrm{UV} / \mathrm{V}$ is spectrophotometer equipped with a temperature program controller (Perkin-Elmer). The optimal renaturation temperature was $79^{\circ} \mathrm{C}$.

PCR amplification of the 16S rRNA gene used primers 5'-AGAGTTTGATCCTGGCTCAG-3' and 5' -TACGGCTACCTTGTTACGACTT-3'. PCR products were sequenced directly using an ABI PRISM BigDye Terminator cycle sequencing ready reaction kit (Perkin Elmer) on an ABI PRISM 377XL DNA Sequencer (Applied Biosystems). The 
sequences of strains DSM 2457 and DSM 1277 and corresponding sequences retrieved from the GenBank database were aligned using the CLUSTAL X program (version 1.64b; Thompson et al., 1997). Evolutionary distances were calculated using the program within the PHYLIP package (Felsenstein, 1993). The phylogenetic tree was constructed according to the neighbour-joining method (Saitou \& Nei, 1987) using the software package TREECON for Windows version 1.3b (Van de Peer \& De Wachter, 1994).

Cells of strains DSM 1277 and DSM 2457 were Gramnegative, curved rods, $0 \cdot 8-1 \cdot 0 \mu \mathrm{m}$ in diameter, non-motile, with a capsule and gas vesicles. Colonies were white, convex, round, entire and $0.5-1.0 \mathrm{~mm}$ in diameter after 7 days incubation on nutrient agar plates. When they grew in liquid medium, they produced pellicles. They produced poly- $\beta$ hydroxybutyrate granules. They could fix free nitrogen while growing on Döbereiner nitrogen-free medium (Döbereiner et al., 1976). Strain DSM 1277 did not grow at 4 or $37^{\circ} \mathrm{C}$, and strain DSM 2457 did not grow at 4 or $50{ }^{\circ} \mathrm{C}$. Optimum growth occurred at $28-30^{\circ} \mathrm{C}$ and $\mathrm{pH} 7 \cdot 0$. Strain DSM 1277 showed no growth at $\mathrm{pH} 5 \cdot 5$ or $11 \cdot 0$, and strain DSM 2457 showed no growth at $\mathrm{pH} 4.5$ but grew at $\mathrm{pH} 11 \cdot 0$. Strain DSM 1277 grew on medium containing $0-2 \cdot 5 \%(\mathrm{w} / \mathrm{v}) \mathrm{NaCl}$, whereas strain DSM 2457 grew on medium containing $0-3 \%(\mathrm{w} / \mathrm{v}) \mathrm{NaCl}$. The two strains were positive for oxidase, catalase and urease activities and negative for DNase, phenylalanine deaminase, lipase (Tween 80 ) and arginine dihydrolase. They could not produce $\mathrm{H}_{2} \mathrm{~S}$ or indole. They could reduce nitrates but could not grow anaerobically with nitrate. Methyl red and Voges-Proskauer tests were negative. The strains hydrolysed aesculin and gelatin but not starch. Details of utilization of carbon sources and production of acid and gas from carbohydrates are given in the species descriptions. Differentiating phenotypic characteristics between these two strains and A. aquaticus DSM $101^{\mathrm{T}}$ and A. rudongensis AS $1.1761^{\mathrm{T}}$ are listed in Table 1.

Analysis of almost-complete 16S rRNA gene sequences (Fig. 1) showed that strains DSM 1277 and DSM 2457 belonged to the genus Ancylobacter. The sequence similarities of strain DSM 1277 with A. aquaticus DSM $101^{\mathrm{T}}$ and $A$. rudongensis AS $1.1761^{\mathrm{T}}$ were respectively $99 \cdot 6$ and $99 \cdot 1 \%$, and the sequence similarities of strain DSM 2457 with $A$. aquaticus DSM $101^{\mathrm{T}}$ and $A$. rudongensis AS $1.1761^{\mathrm{T}}$ were respectively 99.2 and $98.98 \%$. The DNA-DNA relatedness values of strain DSM 1277 with strains DSM $101^{\mathrm{T}}$, AS $1.1761^{\mathrm{T}}$ and DSM 2457 were respectively $51 \cdot 4,56 \cdot 8$ and $40.9 \%$, while the DNA-DNA relatedness values of strain DSM 2457 with strains DSM $101^{\mathrm{T}}$ and AS $1.1761^{\mathrm{T}}$ were respectively 43.7 and $38.8 \%$. These values were the means of three repeated experiments. The pooled standard deviations of all hybridization experiments for strains DSM 1277 and DSM 2457 were respectively $5 \cdot 3$ and $3 \cdot 9 \%$. The DNA G + C content of both strains was $65 \cdot 5 \mathrm{~mol} \%$.

The results of DNA-DNA hybridization suggested that these two strains represent novel species of Ancylobacter. According to the results of our study, we propose to classify
Table 1. Characteristics that differentiate strains DSM 1277 and DSM 2457 from $A$. aquaticus DSM $101^{\top}$ and A. rudongensis AS $1.1761^{\top}$

Data for A. aquaticus DSM $101^{\mathrm{T}}$ were taken from Raj (1976, 1981), Larkin et al. (1977) and Holt et al. (1994). Data for A. rudongensis AS $1.1761^{\mathrm{T}}$ were taken from Xin et al. (2004).

\begin{tabular}{|c|c|c|c|c|}
\hline Characteristic & $\begin{array}{l}\text { DSM } \\
1277\end{array}$ & $\begin{array}{l}\text { DSM } \\
2457\end{array}$ & $\begin{array}{c}\text { DSM } \\
101^{\mathrm{T}}\end{array}$ & $\begin{array}{c}\text { AS } \\
1.1761^{\mathrm{T}}\end{array}$ \\
\hline \multicolumn{5}{|l|}{ Growth at/in: } \\
\hline $37^{\circ} \mathrm{C}$ & - & + & - & + \\
\hline pH $5 \cdot 5$ & - & + & - & - \\
\hline $\mathrm{pH} 10$ & + & + & - & - \\
\hline $3 \% \mathrm{NaCl}$ & - & + & - & + \\
\hline Aesculin hydrolysis & + & + & - & + \\
\hline \multicolumn{5}{|c|}{ Acid production from: } \\
\hline Inulin & + & + & - & - \\
\hline Cellobiose & + & + & - & + \\
\hline Salicin & + & + & - & + \\
\hline Maltose & - & + & - & + \\
\hline Trehalose & - & - & - & + \\
\hline Melibiose & + & + & - & + \\
\hline Lactose & + & + & - & + \\
\hline \multicolumn{5}{|l|}{ Utilization of: } \\
\hline Maltose & + & + & - & + \\
\hline Adonitol & + & + & - & + \\
\hline$\alpha$-Ketoglutarate & + & + & - & + \\
\hline Fumarate & + & + & - & + \\
\hline meso-Erythritol & - & + & - & - \\
\hline Melezitose & + & + & - & - \\
\hline Gluconate & + & - & ND & + \\
\hline Arginine & + & + & ND & - \\
\hline Propionate & + & + & - & + \\
\hline Pyruvate & - & + & + & + \\
\hline Salicin & + & + & - & - \\
\hline Isolation source & Soil & $\begin{array}{l}\text { River } \\
\text { mud }\end{array}$ & Soil & $\begin{array}{c}\text { Root of } \\
\text { Spartina } \\
\text { anglica }\end{array}$ \\
\hline
\end{tabular}

strain DSM 1277 as the type strain of Ancylobacter vacuolatus sp. nov. and strain DSM 2457 as the type strain of Ancylobacter polymorphus sp. nov.

\section{Description of Ancylobacter vacuolatus sp. nov.}

Ancylobacter vacuolatus (va.cu.o.la'tus. N.L. masc. adj. vacuolatus vacuolate).

The characters of type strain were originally reported by Nikitin (1971). Gram-negative, curved rods, $0 \cdot 8-1 \cdot 0 \mu \mathrm{m}$ in diameter, non-motile, with a capsule and gas vesicles. Colonies are white, convex, round, entire and $0 \cdot 5-1 \cdot 0 \mathrm{~mm}$ in diameter after 7 days incubation on nutrient broth agar plates. Can produce pellicles when growing in liquid medium. Produces poly- $\beta$-hydroxybutyrate granules. Fixes free nitrogen while growing on Döbereiner nitrogen-free medium. No growth at 4 or $37^{\circ} \mathrm{C}$ or at pH 5.5 or $11 \cdot 0$. Optimum 


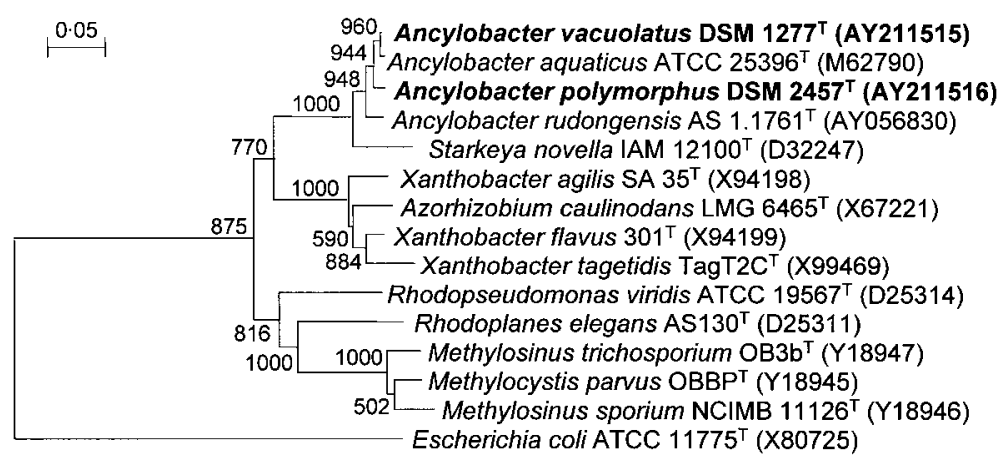

Fig. 1. Phylogenetic tree of strains DSM 1277 and DSM 2457 and related taxa based on 16S rRNA gene sequence comparisons using the neighbour-joining method (Saitou $\&$ Nei, 1987). Accession numbers of reference sequence are given after the strain names. Numbers represent confidence levels from 1000 replicate bootstrap samplings. Bar, 5 substitutions per 100 nucleotide positions. growth at $28-30{ }^{\circ} \mathrm{C}$ and at $\mathrm{pH} 7 \cdot 0$. Grows in $0-2 \cdot 5 \%(\mathrm{w} / \mathrm{v})$ $\mathrm{NaCl}$. Oxidase-, catalase- and urease-positive. Negative for DNase, phenylalanine deaminase, lipase (Tween 80) and arginine dihydrolase. Does not produce $\mathrm{H}_{2} \mathrm{~S}$ or indole. Methyl red and Voges-Proskauer tests are negative. Reduces nitrates. Does not grow anaerobically with nitrate. Hydrolyses aesculin and gelatin but not starch. Utilizes the following substrates as carbon and energy sources: maltose, L-arabinose, fructose, glycerol, mannitol, sorbitol, starch, adonitol, ribose, mannose, aesculin, amygdalin, sodium gluconate, ketoglutaric acid, alanine, proline, fumaric acid, arginine, sodium acetate, sodium malonate, sodium citrate, sodium succinate, sodium propionate, sodium lactate, sodium malate and methanol. Utilizes the following substrates weakly as carbon and energy sources: cellobiose, galactose, glucose, xylose, methyl $\alpha$-D-glucoside, melezitose, sodium formate and salicin. Does not utilize the following substrates as carbon and energy sources: rhamnose, dextrin, lactose, inulin, raffinose, sucrose, trehalose, sorbose, melibiose, dulcitol, inositol, meso-erythritol, sodium tartrate, sodium hippurate and sodium pyruvate. Forms acid but no gas from mannose, ribose, glycerol, mannitol, inulin, sorbitol, galactose, cellobiose, rhamnose, salicin, glucose, arabinose, xylose, melibiose, adonitol, fructose and lactose. Does not form acid or gas from inositol, raffinose, melezitose, starch, glycogen, methyl $\alpha$-D-glucoside, sucrose, maltose, sorbose, trehalose, dulcitol, meso-erythritol or dextrin. The DNA G + C content of the type strain is $65.5 \mathrm{~mol} \%$.

The type strain is strain DSM $1277^{\mathrm{T}}\left(=\mathrm{AS} 1.2807^{\mathrm{T}}\right.$ ), isolated from soil in Russia, previously described as 'Renobacter vacuolatum' (Nikitin, 1971).

\section{Description of Ancylobacter polymorphus sp. nov.}

Ancylobacter polymorphus (po.ly.mor' phus. N.L. masc. adj. polymorphus polymorphic).

Gram-negative, curved rods, $0 \cdot 8-1 \cdot 0 \mu \mathrm{m}$ in diameter, nonmotile, with a capsule and gas vesicles. Colonies are white, convex, round, entire and $0.5-1.0 \mathrm{~mm}$ in diameter after 7 days incubation on nutrient broth agar plates. Can produce pellicles when growing in liquid medium. Produces poly- $\beta$-hydroxybutyrate granules. Fixes free nitrogen while growing on Döbereiner nitrogen-free medium. No growth at 4 or $50{ }^{\circ} \mathrm{C}$ or at $\mathrm{pH} 4 \cdot 5$. Optimum growth at $28-30^{\circ} \mathrm{C}$ and at $\mathrm{pH} 7 \cdot 0$. Grows at $\mathrm{pH} 11 \cdot 0$. Grows in $0-3 \%(\mathrm{w} / \mathrm{v}) \mathrm{NaCl}$. Oxidase-, catalase- and urease-positive. Negative for DNase, phenylalanine deaminase, lipase (Tween 80) and arginine dihydrolase. Does not produce $\mathrm{H}_{2} \mathrm{~S}$ or indole. Methyl red and Voges-Proskauer tests are negative. Reduces nitrates. Does not grow anaerobically with nitrate. Hydrolyses aesculin and gelatin but not starch. Utilizes the following substrates as carbon and energy sources: maltose, methyl $\alpha$-D-glucoside, adonitol, glycerol, glucose, ribose, inulin, L-arabinose, fructose, galactose, mannitol, dextrin, meso-erythritol, xylose, sorbitol, amygdalin, ketoglutaric acid, alanine, proline, fumaric acid, arginine, sodium acetate, sodium malonate, sodium citrate, sodium succinate, sodium propionate, sodium lactate, sodium malate and methanol. Utilizes the following substrates weakly as carbon and energy sources: starch, sucrose, aesculin, melezitose, sodium pyruvate, sodium formate and salicin. Does not utilize the following substrates as carbon and energy sources: trehalose, sorbose, cellobiose, raffinose, melibiose, mannose, lactose, dulcitol, inositol, rhamnose, sodium gluconate, sodium tartrate and sodium hippurate. Forms acid but no gas from mannose, ribose, glycerol, mannitol, inulin, sorbitol, galactose, cellobiose, rhamnose, salicin, glucose, maltose, L-arabinose, xylose, melibiose, adonitol, fructose and lactose; forms neither acid nor gas from inositol, raffinose, melezitose, starch, glycogen, methyl $\alpha$-D-glucoside, sucrose, sorbose, trehalose, dulcitol, meso-erythritol and dextrin. The DNA $\mathrm{G}+\mathrm{C}$ content of the type strain is $65.5 \mathrm{~mol} \%$.

The type strain is strain DSM $2457^{\mathrm{T}}\left(=\mathrm{AS} 1.2800^{\mathrm{T}}=\right.$ NCIMB $10516^{\mathrm{T}}$ ), isolated from river mud (Maclennan et al., 1974).

\section{Acknowledgements}

This work was supported by the Foundation of State Key Basic Research and Development Plan of China (project no. 2001cb108905).

\section{References}

De Ley, J., Cattoir, H. \& Reynaerts, A. (1970). The quantitative measurement of DNA hybridization from renaturation rates. Eur J Biochem 12, 133-142. 
Döbereiner, J., Marriel, I. E. \& Nery, M. (1976). Ecological distribution of Spirillum lipoferum Beijerinck. Can J Microbiol 22, 1464-1473.

DSMZ (1998). Catalogue of Strains, 6th edn. Braunschweig: Deutsche Sammlung von Mikroorganismen und Zellkulturen.

Felsenstein, J. (1993). PHYLIP - phylogeny inference package version 3.5. Distributed by the author. Department of Genome Sciences, University of Washington, Seattle, USA.

Hanson, R. S. \& Phillips, J. A. (1981). Chemical composition. In Manual of Methods for General Bacteriology, pp. 328-364. Edited by P. Gerhardt, R. G. E. Murray, R. N. Costilow, E. W. Nester, W. A. Wood, N. R. Krieg \& G. B. Phillips. Washington, DC: American Society for Microbiology.

Holt, J. G., Krieg, N. R., Sneath, P. H. A., Staley, J. T. \& Williams, S. T. (1994). Nonmotile (or rarely motile), Gram-negative curved bacteria. In Bergey's Manual of Determinative Bacteriology, 9th edn, pp. 65-69. Edited by J. G. Holt. Baltimore: Williams \& Wilkins.

Hugh, R. \& Leifson, E. (1953). The taxonomic significance of fermentative versus oxidative metabolism of carbohydrates by various Gram-negative bacteria. J Bacteriol 66, 24-26.

Larkin, J. M., Williams, P. M. \& Taylor, R. (1977). Taxonomy of the genus Microcyclus Ørskov 1928: reintroduction and emendation of the genus Spirosoma Migula 1894 and proposal of a new genus, Flectobacillus. Int J Syst Bacteriol 27, 147-156.

Maclennan, D. G., Ousby, J. C., Owen, T. R. \& Steer, D. C. (1974). Microbiological production of protein. UK patent no. GB1370892.

Marmur, J. (1961). A procedure for the isolation of DNA from microorganisms. J Mol Biol 3, 208-218.

Marmur, J. \& Doty, P. (1962). Determination of the base composition of deoxyribonucleic acid from its thermal denaturation temperature. J Mol Biol 5, 109-118.

Nikitin, D. I. (1971). A new soil microorganism - Renobacter vacuolatum, gen. et sp. n. Dokl Akad Nauk SSSR 198, 447-448 (in Russian).

Ørskov, J. (1928). Beschreibung eines neuen Mikroben, Microcyclus aquaticus, mit eigentümlicher Morphologie. Zentralbl Bakteriol Parasitenkd Infektionskr Hyg Abt 1 Orig 107, 180-184 (in German).
Raj, H. D. (1976). A new species: Microcyclus marinus. Int J Syst Bacteriol 26, 528-544.

Raj, H. D. (1981). The genus Microcyclus and related bacteria. In The Prokaryotes. A Handbook on Habitats, Isolation and Identification of Bacteria, pp. 630-644. Edited by M. P. Starr, H. Stolp, H. G. Trüper, A. Balows \& H. G. Schlegel. New York: Springer.

Raj, H. D. (1983). Proposal of Ancylobacter gen. nov. as a substitute for the bacterial genus Microcyclus Ørskov 1928. Int J Syst Bacteriol 33, 397-398.

Raj, H. D. (1989). Oligotrophic methylotrophs: Ancylobacter (basonym "Microcyclus" Ørskov) Raj gen. nov. Crit Rev Microbiol 17, 89-106.

Saitou, N. \& Nei, M. (1987). The neighbor-joining method: a new method for reconstructing phylogenetic trees. Mol Biol Evol 4, 406-425.

Schreier, J. B. (1969). Modification of deoxyribonuclease test medium for rapid identification of Serratia marcescens. Am J Clin Pathol 51, 711-716.

Smibert, R. M. \& Krieg, N. R. (1981). General characterization. In Manual of Methods for General Bacteriology, pp. 409-443. Edited by P. Gerhardt, R. G. E. Murray, R. N. Costilow, E. W. Nester, W. A. Wood, N. R. Krieg \& G. B. Phillips. Washington, DC: American Society for Microbiology.

Sydow, H. \& Sydow, P. (1904). Novae fungorum species. Ann Mycol 2, 162-174.

Thompson, J. D., Gibson, T. J., Plewniak, F., Jeanmougin, F. \& Higgins, D. G. (1997). The CLUSTAL_X windows interface: flexible strategies for multiple sequence alignment aided by quality analysis tools. Nucleic Acids Res 25, 4876-4882.

Van de Peer, Y. \& De Wachter, R. (1994). TREECON for Windows: a software package for the construction and drawing of evolutionary trees for the Microsoft Windows environment. Comput Appl Biosci 10, 569-570.

Xin, Y. H., Zhou, Y. G., Zhou, H. L. \& Chen, W. X. (2004). Ancylobacter rudongensis sp. nov., isolated from roots of Spartina anglica. Int J Syst Evol Microbiol 54, 385-388. 